\title{
The Concept of «Right» and the Focal Point of Juridicity in Debate between Villey, Tierney, Finnis and Hervada
}

\author{
El concepto de «derecho» y el punto focal de la juridicidad \\ en debate entre Villey, Tierney, Finnis y Hervada
}

\section{Petar PoPOVIC}

Pontificia Università della Santa Croce (Italia)

petar.popovic@yahoo.com

\begin{abstract}
The article revisits and seeks to clarify and provide with new perspectives the debate between the theoretical approaches of four authors - Michel Villey, Brian Tierney, John Finnis and Javier Hervada - in their accounts of the contemporary formulation of the concept of «ius». Although all authors analyzed in the paper share common thomistic roots in their respective argumentations on the essential meaning and content of the concept of «right», they still differ in their accounts with regard to the understanding of Aquinas's classical juridical realism, the relation between «law» and «right» and the role of subjective rights in history and in today's juridical discourse. The paper seeks to highlight how such comparative perspective reveals not only the contrasts in the theoretical accounts of these authors with regard to the structural «locus» of the focal point of juridicity, but also renders manifest certain perspectives of integration of each approach with contributions achieved by the other interlocutors of the debate.
\end{abstract}

Keywords: classical juridical realism; right; ius; law; natural law; juridicity; Aquinas, Villey, Tierney, Finnis, Hervada.
Resumen: El artículo revisa y busca aclarar y proporcionar con nuevas perspectivas el debate entre los enfoques teóricos de cuatro autores - Michel Villey, Brian Tierney, John Finnis y Javier Hervada- en sus relatos de la formulación contemporánea del concepto de «ius». Aunque todos los autores analizados en el documento comparten raíces tómisticas comunes en sus respectivas argumentaciones sobre el significado y contenido esencial del concepto de «derecho», todavía difieren en sus relatos con respecto a la comprensión del realismo jurídico clásico de Tomás de Aquino. El artículo busca destacar cómo esta perspectiva comparativa revela no sólo los contrastes en los relatos teóricos de estos autores con respecto al «locus» estructural del punto focal de la juridicidad, sino que también pone de manifiesto ciertas perspectivas de integración de cada enfoque con las contribuciones alcanzadas por los otros interlocutores del debate.

Palabras clave: realismo jurídico clásico; derecho; ius; ley; la Ley natural; juridicidad; Aquinas; Villey; Tierney; Finnis; Hervada. 


\section{INTRODUCTION}

t seems that today's common answer to an enduring problem of legal philosophy - namely, what is the ground of things that are owed and how is it that someone can claim «this is owed to me» ${ }^{1}-$ amounts to the understanding of the juridical phenomenon exclusively in two foundational categories: that of the positive legal norm (juridical fact in the objective sense) and that of subjective right-claim (juridical fact in the subjective sense) ${ }^{2}$. In the second half of the twentieth century a French philosopher of law, Michel Villey, published a series of articles and books in which he challenged these dominant understandings of «right $»^{3}$. Instead of identifying the essence of the juridical phenomenon with a system of norms as rules of conduct ${ }^{4}$, or to a concept of subjective rights conceived predominantly as powers in function of the individual and his liberties ${ }^{5}$, Villey proposed a restatement of the classical realistic concept of «right» - «ius» - as conceived by Aristotle, the jurists of Ancient Rome and

1 Hittinger, R., The First Grace: Rediscovering the Natural Law in a Post-Christian World, ISI Books, Wilmington, 2003, p. 115.

2 ERrázuriz, C. J., «Sul rapporto tra diritto e giustizia: valore e attualità della tradizione classica e Cristiana», Persona y Derecho, 40 (1999), pp. 337-359. See also, Villey, M., Le droit et les droits de l'homme, Presses Universitaires de France, Paris, 1983, pp. 24-25.

3 Since this paper seeks to present various proposals for a contemporary restatement of the antique and medieval concept of «ius», throughout the paper we will use the term «right» primarily in a sense that corresponds to this pre-modern concept, namely, as something that objectively indicates what is just. The term «right» is capable of designating this objective sense in most European languages («droit» in French, «derecho» in Spanish, «diritto» in Italian), despite the dominant contemporary cultural tendency to understand this term in the sense of subjective rights as faculties of claiming. In the English language, however, the juridical phenomenon in its objective meaning is usually denoted by the term «law», whereas the term «right» is reserved exclusively for the category of rights understood in the modern subjective sense. For the difficulties in harmonizing the legal terminology of the European continental tradition and the Anglo-Saxon tradition with regard to the translations of the concept of «ius», see CAPARROS, E., «Presentation of the English Edition», in Hervada, J., Critical Introduction to Natural Law, Wilson \& Lafleur Ltée, Montréal, 2006, pp. xi-xiii; VoILLEY, G., «Translator's Introduction», in ViLley, M, «Epitome of Classical Natural Law (Part One)», Griffith Law Review, 9 (2000), p. 75. This latter article is an English translation of VILLEY, M., «Abrégé du droit naturel classique», in Lecons d'bistoire de la philospobie du droit, Dalloz, Paris, 2002, pp. 109-165. The text was originally published in the 1961 edition of Archives de philosophie du droit.

4 Villey, M., «Sur les essais d'application de la logique déontique au droit», Archives de philosopbie du droit, 17 (1972), p. 407; ID., «Le droit dans les choses», in AMSELEK, P. and GRZEGORCZYK, C. (ed.), Controverses autour de l'ontologie du droit, Presses Universitaires de France, Paris, 1989, p. 12.

5 VIlley, M., «Dikaion - Torah (II). Seconde scolastique», in Critique de la pensée juridique moderne, Dalloz, Paris, 1976, p. 35. 
St. Thomas Aquinas. His research catalyzed a debate in legal philosophy and history on many levels.

In this paper we will present the course of the debate circumscribed to the conceptual exchange of ideas between four authors: Michel Villey, Brian Tierney, John Finnis and Javier Hervada. All these authors share a common philosophical framework - a proposal for some form of recovery of the classical thomistic approach to the juridical phenomenon. Still, they differ significantly on a number of particular arguments regarding the essence of the classical concept of «ius» and of the concrete modalities of its contemporary restatement. While presenting their arguments, we will attempt to identify the focal point of juridicity in their respective accounts of the concept of «right»-i.e., what, in the ultimate juridical analysis, constitutes something as $\ll{\text { right }{ }^{6}}^{6}$. Such analysis will serve to illuminate the conceptual differences between these four authors, and perhaps cast light on certain perspectives of integration of particular arguments into their respective theories.

Another reason to focus precisely on these four authors lies in the fact that they themselves often developed an argumentation on the concept of «right» in direct (or at least implicit) dialogue with one another. Thus, they have created a distinctive, at times mutually critical, dialogical body of work that the reader could benefit from reading as a single argumentative stream.

Although numerous pages of their debate were devoted also to the issues of historical and terminological matters, we will focus on these levels of debate only collaterally and insofar as they contribute to a clearer understanding of strictly juridical determination of the concept of «ius».

Recently, when referring to this debate, one of its participants affirmed that it is «deeply regrettable that so much scholarly time has been diverted to tracing differences that are in the last analysis almost imaginary» ${ }^{7}$. This paper attempts to challenge this claim by showing that the scientific conversation of

6 For this task, we will adopt the understanding of the concept of «juridicity» of Javier Hervada, the only author among the four presented in the paper to give a systematic account of this concept. However, for the purposes of this paper, we shall initially employ Hervada's concept of juridicity in its broader meaning on a «content-neutral» level of abstraction in order to filter through it the theoretical accounts of each author. In this broader meaning Hervada understands «juridicity» as essentially the formal constitutive factor of the specifically juridical dimension in facts and relations. As such, it has a focal point - a concrete cause that renders the fact or relation in question juridical.

7 FINNIS, J., «Grounding Human Rights in Natural Law», American fournal of furisprudence, 60 (2015), p. 214. 
the authors in question constitutes a central contribution to a more adequate understanding of the concept of «right», as well as to the contemporary recovery of the classical concept of «ius».

\section{Michel Villey, «Right» AS «Just Share» AND the CritiQue of Subjective Rights}

In a series of books and articles published throughout the second half of the last century, the French philosopher of law, Michel Villey, was the first ${ }^{8}$ author to put forward a proposal for the restoration of the classical realistic concept of «right», in contrast to the modern semantics of conceiving the legal phenomena in a predominantly subjectivist sense. Villey claimed that the concept of «subjective rights» has been the central notion for the systematic elaboration of legal science since the fourteenth century ${ }^{9}$. William Ockham, Hugo Grotius, Thomas Hobbes, John Locke, Immanuel Kant and other authors who approached the legal phenomena through the optic of «subjective rights» have constructed their theories around an understanding of «ius» that posits the individual, the description of his juridical qualities and faculties, as the systematic starting point ${ }^{10}$.

«All they discern in [nature as the source of subjective rights] are individual 'rights', powers or liberties, naturally unlimited as long as the positive law proceeding from the assent of citizens (and therefore indirectly proceeding from these very liberties) does not limit them $»^{11}$.

\subsection{Villey's Preference for the Classical Realistic Concept of «Right»}

Villey highlights that this modern notion of «right» is born in clear contrast to the classical, objective concept of $\langle i u s\rangle^{12}$, developed by Aristotle («dikaion»), the Roman jurisprudence and Thomas Aquinas within the

8 Villey's proposal for the revival of the classical pre-modern concept of «right» in today's legal culture dominated by the category of «subjective right» was labelled a «detonator» of his entrance to the world of the philosophy of law. See RaBBI-BALDI Cabanillas, R., La filosofía jurídica de Michel Villey, EUNSA, Pamplona, 1990, p. 438.

9 Villey, M., «Epitome of Classical Natural Law (Part Two)», Griffith Law Review, 10 (2001), p. 171.

10 Villey, M., La formation de la pensée juridique moderne, Presses Universitaires de France, Paris, 2013, p. 228.

11 VILLEY, M., «Epitome of Classical Natural Law (Part Two)», op. cit., p. 171.

12 Ibidem. 
philosophical framework of metaphysical realism ${ }^{13}$. In this classical realistic framework, the juridical dimension, the «right», was inherent in «nature». The jurists of antiquity and medieval times have approached the concept of «ius» from «the observation of the order inherent in the social body, (...) of the 'cosmic nature' $\gg^{14}$. In order to understand «right» in classical juridical realism, Villey affirms that one must abandon the modern exclusive perspective of the centrality of the individual person, his powers and desires, and «entirely free oneself from these post-Kantian concepts which are so deeply embedded in contemporary thought $\gg^{15}$. In the first place, this entails an understanding of «ius» as the object of the virtue of justice. The two terms are so closely interwoven that Aristotle used the same term («dikaion») to designate both «justice» and «right». Thomas Aquinas defined «ius» precisely as the object of justice, «that which is just», in the Treatise on Justice of his Summa Theologiae ${ }^{16}$. Secondly, «ius» is essentially defined with relation to a prior order impressed in the nature of things ${ }^{17}$. and which justice $a$ posteriori seeks to procure. Therefore, according to Villey, between a prior «cosmic» order and the posterior act of justice (which consists in $«$ giving» ${ }^{18}$, procuring this order) there is an intermediary dimension which delineates the very object of «giving» according to the prior order. And that peculiar dimension determines the content of the concept of «ius».

«In order to establish the right (...) classical juridical science does not begin with the individual, but objectively, with the bulk of social goods to be shared. The right of each is a quota. A right is not therefore the 'attribute' of the individual considered in isolation, but a thing, an objective thing (an 'incorporeal thing'), a delimited quantity of prerogatives or duties» ${ }^{19}$.

13 Villey, M., La formation de la pensée..., op. cit., p. 224.

14 ID., «La genèse du droit subjectif chez Guillaume d'Occam», Archives de philosophie du droit, 9 (1964), p. 103. This English translation from the French original text (as well as the other translations from the respective authors' original writings in French, Spanish or Italian throughout this paper) is ours.

15 ID., «Epitome of Classical Natural Law (Part One)», op. cit., p. 81.

16 Thomas Aquinas, S.Th. II-II, q. 57.

17 «There is no other procedure [for the determination of the just allocation, the 'portion due to each' in defining the relations between two persons juridically] but to interrogate nature, and to attempt to recognize the order which it perhaps conceals - an objective, and therefore juridical order». VILley, M., «Epitome of Classical Natural Law (Part One)», op. cit., p. 96.

18 «In its specific meaning, justice tends to give to each his own (suum cuique tribuere)...», see ibid., pp. $85-86 ; \ll(\ldots)$ justice means to 'allocate to each his right'...», see ibid., p. 94.

19 VILley, M., «Epitome of Classical Natural Law (Part Two)», op. cit., p. 174. 
Within classical juridical realism the concept of «ius» denotes the «objective just relation $\gg^{20}$ constituted by a just and harmonious order inherent in the «natural social body» ${ }^{21}$, in which every person and each thing finds its well fixed place ${ }^{22}$. «Ius» as «objective just relation» is, then, such «just proportion» that exists between external things (res exteriores) distributed between persons ${ }^{23}$.

Applied to the individual person, «ius» can only be defined, according to Villey, as a «share» that belongs to him in justice. From the perspective of the individual, «ius» is his personal status, his juridical condition, or, generally, that precise thing (those immovables, credits, debts, utilities or advantages) which constitutes his «share» within the objective just relation ${ }^{24}$. However, «ius» can, according to Villey, be transposed to signify a juridical phenomenon strictly from the perspective of the individual person only in a secondary structural moment, since it is never focalized exclusively in human nature considered in isolation. The content of the classical concept of «ius» is broader than mere subjective claims and advantages of the individual person: «my right, that which is due me (...) may also be a sanction $»^{25}$. Indeed, the concept of «ius» implies an already fixed order of «supra-interpersonal» relations which limits the free-standing individual «power» and neutralizes its putative reformulation as an absolute juridical claim ${ }^{26}$. Individual «power» is, thus, structurally located in the sphere of pre-juridical content which can never be formally constitutive of the essence of «ius».

Such understanding of «ius» imbued the mentality of Roman jurists, who, according to Villey, provided Aristotle's «dikaion» (probably mediated through Stoic eclecticism), with the systematics of a «scientific form $»^{27}$. In classical Rome, «ius» was not identified, for example, with the «power» or right-claim of the creditor, but with the obligation itself-«vinculum iuris», the objective relation between the creditor and the debtor ${ }^{28}$. It was also used to

20 VILLEY, M., «La genèse du droit...», op. cit., p. 103; ID., La formation de la pensée..., op. cit., p. 243.

21 ID., La formation de la pensée..., op. cit., p. 243.

22 ID., «Les origines de la notion de droit subjectif», in Lecons d'bistoire de la philospobie du droit, p. 234.

23 ID., «Dikaion - Torah (II)», op. cit., p. 42.

24 ID., «La genèse du droit...», op. cit., p. 103.

25 ID., La formation de la pensée..., op. cit., p. 571.

26 ID., «La genèse du droit...», op. cit., p. 104.

27 ID., «Les origines de la notion...», op. cit., p. 235.

28 ID., «La genèse du droit...», op. cit., p. 106. 
designate the whole regime or juridical institute pertaining to a legal condition or status of the individual person. Today's legal culture, which was formed in the framework of «subjective rights», finds it very hard to understand, and even to translate a concrete application of the term «ius», for example, when declaring a «right not to elevate one's immovables» («ius altius non extollendi») ${ }^{29}$. But in Roman juridical culture, as well as in twelfth-century medieval culture steeped in the legal renaissance of Roman juridical categories, «right» is essentially a «share» in a thing allocated through a natural order, and not power over things ${ }^{30}$. Even though Villey does not deny that factual juridical «situations» later qualified by the term «subjective rights» were already present in Roman legal language, and Roman jurists certainly knew that individuals have powers attributed to them ${ }^{31}$, the classical juridical culture never envisaged such «powers» as being vested with the essence of the concept of $\left\langle\right.$ right $»^{32}$.

\subsection{The Genesis of the Concept of «Subjective Rights»}

Although Villey admits that it is not easy to determine with precision the exact moment when the term «ius» began to signify essentially the «subjective right», he proposes a chronology of various philosophical stages which contributed to the crossing of the «watershed $»^{33}$ from the classical to the modern vision of «right». He refers to these stages of development as «gradual slides» $(\ll \text { glissements») })^{34}$.

The first contributing factor was, according to Villey, the Christian cultural influence with regard to the increasing appreciation of the value of individual's dignity and initiative. At the same time, a juridical Augustinianism fa-

29 VILLEY, M., «Les institutes de Gaius et l'idée du droit subjective», in Lecons d'bistoire de la philospobie du droit, p. 182.

30 ID., «La genèse du droit...», op. cit., p. 107.

31 ID., «Les institutes de Gaius...», op. cit., p. 185; ID., «La genèse du droit...», op. cit., p. 105.

32 ID., «La genèse du droit...», op. cit., p. 105. To claim the opposite would, according to Villey, amount to a forced projection of modern categories of subjective rights retroactively to Roman law. See VIlley, M., «Les institutes de Gaius...», op. cit., p. 169.

33 ID., La formation de la pensée..., op. cit., p. 261. We preferred here to translate the French expression «ligne de partage» originally used by Villey, with an English word of similar meaning - «watershed»- because it is later also used, as we shall see, by other authors presented in this paper, to denote the same argumentative moment. See FinNIs, J., Natural Law and Natural Rights, 2d ed., Oxford University Press, Oxford, 2011, pp. 206-7, 424, 465-6.

34 VILLEY, M., «Les origines de la notion...», op. cit., p. 238. 
voured the postulate of moral law (understood as essentially rules of conduct) as a unique source of juridicity, reduced largely to the sole moral dimension of individual human action ${ }^{35}$. The second factor was the dissolution of Roman legal institutions, as well as the subsequent stratification of medieval society into networks of powers and initiatives, whereby each social group envisioned its proper juridical status in the predominant terms of «advantages» ${ }^{36}$. Villey highlights that the jurisprudential work of medieval «glossators» hinted in numerous aspects at the formation of the modern subjectivist juridical language. The «glossators'» texts, however, did not yet place «ius» in the conceptual realm of faculties or claims understood essentially in the subjectivist sense $^{37}$. Still, the thirteenth century work of Thomas Aquinas witnesses to a mainstream juridical mentality which, as Villey highlights, clearly shows the intention to understand «ius» as an autonomous concept, elaborated by the Angelic Doctor in question 57 of IIa IIae in his Summa Theologiae. Even Aquinas's systematization bears witness to his understanding that «ius» is simply not reducible to the matters of law as rules of conduct, treated in a structurally separate part of his Summa - Ia IIae ${ }^{38}$. In Villey's reading of Aquinas, nothing could be further from the concept of «ius» than to predicate individual «power» to its essential meaning ${ }^{39}$, or to define «ius» as essentially a «law», rather than as a just thing ( $\ll$ res iusta» $)^{40}$.

35 VILLEY, M., «La genèse du droit...», op. cit., pp. 110-111; ID., «Les origines de la notion...», op. cit., p. 238; ID., «Dikaion - Torah (II)», op. cit., p. 39. Villey refers to this stage as the «eclipse» of the concept of «ius» as the just distribution of things in favour of the «law», or the period when Torah absorbed the «dikaion». See VILley, M., «Dikaion - Torah (II)», op. cit., pp. 37-39. This juridical Augustinianism favoured a biblical vision of justice, not influential to Aristotle or to Roman jurists, which subsequently led to a confusion and, ultimately, absorption of right by morality. See VILley, M., La formation de la pensée..., op. cit., p. 240.

36 ID., «Les origines de la notion...», op. cit., pp. 238-239; ID., La formation de la pensée..., op. cit., pp. 249-250.

37 «The subjective sense of the word 'ius' still constitutes but an accidental feature, a reflection of the principal sense». VILLEY, M., «Les origines de la notion...», op. cit., p. 240. This particular argument will be the immediate object of numerous subsequent critiques - especially by Brian Tierney - on a historical level and with reflections on a juridical level of argumentation. ID., «Dikaion - Torah (II)», op. cit., pp. 39-40.

39 ID., «La genèse du droit...», op. cit., p. 107.

40 ID., «Si la théorie générale du droit, pour Saint Thomas, est une théorie de la loi», Archives de philosophie du droit, 17 (1972), p. 428; «It is in this textual locus where St. Thomas, while explicitly treating the problem of the definition of right, firmly distinguishes between 'ius' and 'lex'. It is of little interest to me that in other places of the text, where this problem was not at issue, he may happen to tend toward a contrary and improper language of some of the authorities he refers to (...)». See VILley, M., «Sur les essais...», op. cit., p. 408. 
Even if the idea of the «gradual slide» towards a subjectivist sense of «ius» is already practical in juridical experience, and probably latent in opinion and in vulgar semantics in the Middle Ages, Villey claims that nothing permits us to conclude that the word «ius» was meant to essentially denote «subjective right» before the fourteenth century ${ }^{41}$. For a definitive crossing of the «watershed» from the classical to the modern vision of «right», a new contextual vision of the world, contrasted to the ancient classical one, was needed ${ }^{42}$.

«In fact, knowing the exact date of birth of subjective right (which is, after all, impossible to determine with certainty) leaves me completely indifferent; what interests me is to understand which philosophical and juridical system this concept is in solidarity with $\gg^{43}$.

The ultimate foundations of Villey's arguments are not primarily historical. He seeks to explain the genesis of «subjective rights» on a deeper level of progressively individualistic social dynamics. In his view, juridical subjectivism is the direct effect of a philosophical context which gravitates around the individual and the juridical priority of his «powers», liberties, utilities and interests ${ }^{44}$. Villey was convinced that William Ockham ultimately provided the subjectivist tendencies of medieval legal discourse with systematic rigour in his fourteenth century works, such as Opus nonaginta dierum (1332-1334) and, more generally, Breviloquium (1341-1342). Within his nominalist philosophy, Ockham identified the concept of «right» essentially with a system of individual «powers», where the «potestas absoluta et legislativa» of God is the supreme centre of power, while networks of subordinated powers and laws of social groups and individuals are thereby derived $^{45}$. According to Villey, the Copernican revolution which was triggered in the fourteenth century was subsequently fully developed by Hugo

41 VILLEY, M., «La genèse du droit...», op. cit., p. 110.

42 ID., «Les origines de la notion...», op. cit., . 244.

43 ID., La formation de la pensée..., op. cit., pp. 260-261.

44 See Sol, T., «La controverse Villey-Tierney sur la naissance du droit subjectif au XII siècle: difficultés et valeur heuristique d'un anachronisme conceptual», in LAURENT-BONNE, N. and PrÉvost, X. (ed.), Penser l'ordre juridique médiéval et moderne. Regards criosés sur les méthodes des jurists, Lextenso éditions, LGDJ, Paris, 2016, p. 218. See also VilLEY, M., «La genèse du droit...», op. cit., p. 121.

45 VILLEY, M., «La genèse du droit...», op. cit., pp. 120-127. 
Grotius in the sixteenth century. After that, «right» would no longer be understood as an objective just relation established by a prior fixed order of individual and social ontology ${ }^{46}$.

«Already with William Ockham we have seen nominalism generate both juridical positivism and the idea of subjective right (...) He will posit the idea of individual power or the subjective right and all its derivations, like that of the law understood as an emanation of individual power, at the centre of juridical science. He will discard any other possible source of the juridical order, and deny any possibility of extracting juridical relations from nature» ${ }^{47}$.

\subsection{A Critical Assessment of Villey's Concept of «Right» and the Focal Point of furidicity}

Villey was convinced that classical juridical realism is capable of «providing the same services» of today's semantics of subjective rights and liberties, «while using another, more accurate language ${ }^{48}$. The pre-modern concept of «ius» and all its linguistic apparatus is simply more adequate to conceptually grasp the essence of «right». In this perspective, the category of subjective rights cannot be viewed, according to Villey, as a product of conceptual progress or evolution. «Ius» and subjective rights are two different, concurring concepts ${ }^{49}$.

But why is the classical realistic concept of «right» superior to the notion of subjective rights?

As we have seen, Villey is convinced that any attempt to systematically posit the focal point of juridicity essentially in the «powers», liberties, interests and utilities of the individual is defective and impoverishes juridical

46 Villey, M., «Les origines de la notion..., op. cit., pp. 221-227. The exact term itself - «subjective right» - seems to appear for the first time in the eighteenth century works of the jurist Georg Darjes (1714-1791), who was the first to propose the designation of this term as applied to «ius» considered essentially as a faculty of the individual. Regardless of the concrete history of terminological nuances, Villey highlights that Ockham's work was decisive in this conceptual (rather than terminological) «revolution». For the genesis and development of the term «subjective right», especially with regard to Georg Darjes, see GUZMán BRITO, A., «Historia de la denominación del derecho-facultad como 'subjectivo'», Revista de Estudios Histórico-furídicos, 25 (2003), pp. 421-422, 426-427, 434-435, 437-441; See also VILLEY, M., «La genèse du droit..», op. cit., pp. 100-102.

47 ID., La formation de la pensée..., op. cit., p. 272

48 ID., «Epitome of Classical Natural Law (Part Two)», op. cit., p. 172.

49 Sol, T., «La notion de droit subjectif chez Villey et Hervada», Ius Ecclesiae, 28 (2016), p. 324. 
discourse. By structurally relegating any prior natural order - or what is left of it after nominalistic and kantian deconstruction of universals such as «human nature» - to a meta-juridical dimension and by predicating juridicity exclusively to individual «powers» limited only by positive law, we are trapped in the framework of legal positivism.

Villey's Anglo-Saxon contemporaries centred the juridical debate on questions of whether and how positivism should be grounded in some kind of morality $^{50}$, on the need to secure a $\ll$ minimum content of natural law ${ }^{51}$, or on an attempt to establish a link between «right» and the thomistic tradition of natural law ${ }^{52}$. Villey seems to have been mostly unconvinced of the necessity to graft the concept or «right» directly on the theory of natural law, in order to provide some moral grounding to the specifically juridical dimension. Instead, he clearly claimed that «ius» cannot be reduced to a derivation from moral law ${ }^{53}$ and that moral law (which guides the moral conduct or the individual) does not have the primary purpose to measure the $\ll$ just proportion ${ }^{54}$.

50 HarT, H.L.A., «Positivism and the Separation of Law and Morals», Harvard Law Review, 71 (1958), pp. 593-629; FULLER, L.L., «Positivism and Fidelity to Law: A Reply to Professor Hart», Harvard Law Review, 71 (1958), pp. 630-672.

51 «Indeed, the continued reassertion of some form of Natural Law doctrine is due in part (...) to the fact that despite a terminology, and much metaphysics, which few could now accept, it contains certain elementary truths of importance for the understanding of both morality and law. These we shall endeavour to disentangle from their metaphysical setting and restate here in simpler terms (...) Such universally recognized principles of conduct which have a basis in elementary truths concerning human beings, their natural environment, and aims, may be considered the minimum content of Natural Law, in contrast with the more grandiose and more challengeable constructions which have often been proffered». See HaRT, H.L.A., The Concept of Law, 2d ed., Oxford University Press, Oxford, 1994, pp. 188, 193.

52 Almost all philosophers of law rooted in the thomistic tradition in the last half a century, regardless of their mutual critiques on other aspects of the theory of natural law, ground both, natural rights and positive law in natural law almost without any reference to the classical realistic concept of «ius». See, for example, Veatch, H. B., Human Rights: Fact or Fancy, Louisiana State University Press, Baton Rouge, 1985; George, R. P., «Natural Law and Positive Law», in In Defense of Natural Law, Oxford University Press, New York, 1999, pp. 102-112. Ralph McInerny was a rare example of engaging with Villey's thesis when discussing the juridical (hence, not merely historical) structural link between «ius» and natural law. See MCINERNY, R., «Natural Law and Human Rights», American fournal of Jurisprudence, 36 (1991), pp. 1-14.

53 VILleY, M., «Dikaion - Torah (II)», pp. 40, 42.

54 ID., «Si la théorie générale...», op. cit., pp. 429-430. «First of all (...) the science of the just, as I presented it, is but a moment of morality. It is one thing to define objectively the just relations (justum - ius); it is another thing to penetrate the intention which makes man subjectively just». See Villey, M., «Epitome of Classical Natural Law (Part One)», op. cit., p. 88. Italics in the quotation are reported from the original text. 
Interestingly, in at least one place of his work, Villey does seem to open up a structural space for a consideration of «right» as an «effect» (and not mere deduction) of the law, insofar as law is intended to denote the «divine plan that governs the cosmic order $»^{55}$. Elsewhere, he explicitly claims that, according to the classical doctrine, «the just distribution, that is, the juridical order, corresponds to a law, which is, above all, natural law» ${ }^{56}$. Unfortunately, he does not develop a complete theoretical account of the juridical dimension of natural law with regard to his concept of «right». Villey's identification of natural law as solely a moral phenomenon, without taking into account its juridical dimension, could present a weakness to his theory, especially when confronted with his claim that «ius» is constituted according to an already fixed order. Postulating a juridical dimension to natural law could contribute to a more adequate explanation of the legal aspect of this fixed order, i.e., of the distribution prior to and constitutive of the «objective just relation».

As we have seen, there is no doubt that the very essence of the concept of «ius» is the «objective just relation», the «just share» that belongs to the person, or just «proportion» that exists between external things (res exteriores) distributed between persons. We shall not enter here into the details of the ongoing debate whether Villey understood «ius» as essentially a relation or substance $^{57}$. We should, however, address the question of what formally constitutes the focal point of juridicity in his theory. It is clear that an external thing (in the broadest sense of the term, «res», a «thing», «une chose») ${ }^{58}$ constitutes the «share» (advantage or disadvantage) of the individual person according to a prior fixed order. Since Villey negates any predication of juridicity to this prior fixed «cosmic» order, this thing, therefore, becomes due in justice («just share») exclusively in the perspective of the objective just relation ${ }^{59}$. The concept of «right» and the focal point of juridicity, hence, in the final analysis, could be seen as overlapping in his account, and reducible to the objective just relation. Nonetheless, while the concept of «right» is wholly identified with

5 VILLEY, M., «Si la théorie générale...», op. cit., p. 429.

56 ID., La formation de la pensée...», op. cit., p. 593. Italics original.

57 For two essential analysis on metaphysical categorization of Villey's concept of «ius», see SoL, T., «La notion de droit subjectif», pp. 334-344; SCHOUPPE, J.-P., «Réflexions sur la conception du droit de M. Villey: une alternative à son rejet des droits de l'homme», Persona y Derecho, 25 (1991), pp. 151-169.

58 ID., «Le droit dans...», op. cit., p. 13.

59 ID., «La genèse du droit...», op. cit., p. 103. 
this relation, the focal point of juridicity is, on the other hand, structurally observed from a different perspective within this relation. Namely, an external thing becomes the individual's «share» due in justice only insofar as it is pertaining to the objective just relation.

\section{Brian Tierney, Historical Criticism of Villey's Thesis AND THE UNDERLYING CONCEPT OF «RIGHT»}

\subsection{Tierney's Critique of Villey's Thesis on the Genesis of Subjective Rights}

A distinguished historian of medieval and modern origins of jurisprudence, political theory and Western constitutional thought, Brian Tierney, has presented in his works what can truly be called a «most pertinent refutation of Villey's thesis» ${ }^{60}$. In his account of the origin of Western rights theories, based more on the analysis of occurrences of terminological aspects and on historical contexts than on a fully-fledged juridical argumentation, Tierney has claimed that various elements of Villey's theory of the concept of «ius» are «open to objections on points of detail» ${ }^{61}$. The main points of Tierney's critique, on a historical base, are the following. First, Roman jurists could have easily been more familiar with some forms of juridical discourse resembling the language pattern of individual rights than Villey is ready to concede (though not to the extent of undermining the essential meaning of «ius» as «objective just relation» $)^{62}$. Second, the creative jurisprudence of twelfth century «glossators» of Roman law, as well

60 Sol, T., «La controverse...», op. cit., p. 214.

61 TierneY, B., «Villey, Ockham and the Origin of Individual Rights», in The Idea of Natural Rights: Studies on Natural Rights, Natural Law and Church Law 1150-1625, Eerdmans, Grand Rapids, 2001, p. 30.

62 Ibid., pp. 15-19. Villey would have probably, as an answer to this critique, repeated his claim that philosophers of law from the modern subjectivist turn in fourteenth century onwards (including contemporary ones) often developed forced projections of modern categories of subjective rights retroactively to Roman law, thus pushing the Roman concept of «ius»- not easily translatable in modern languages - into a framework for which it was not originally coined. See VILLEY, M., «Les institutes de Gaius...», op. cit., pp. 169-170. Tierney adds to his critique that Villey could have easily been overtly selective in the texts he chose to illustrate the meaning of «ius», draping his whole theory of right around them and discarding, to better suit his main arguments, other occurrences where language seems to have suggested a more subjectivist approach (for example, when terms «potestas» or «dominium» add a different aspect to the objectivist understanding of the term «ius»). See TierneY, B., «Villey, Ockham...», op. cit., pp. 17-18. 
as canonical texts from twelfth and thirteenth century, obviously articulated $a$ language of subjective rights that could not be qualified simply as undifferentiated assemblage of mere references to usages in popular, vulgar discourse. This, according to Tierney, seems to refute Villey's argument on the fourteenth century semantic «copernican turn» he attributed to William Ockham ${ }^{63}$.

Regardless of historical issues of texts and contexts, however relevant, the main point of our argumentation is centred on a juridical analysis of Tierney's concept of $\ll$ right ${ }^{64}$. Does Tierney engage in a juridical debate with Villey's understanding of the concept of «ius», and, if so, can we synthesize particular traits of a contrasting concept of «right» underneath his historical argumentation?

\subsection{Tierney's furidical Critique of Villey's Concept of «Right» and His Alternative Approach}

Tierney begins his specifically juridical objection to Villey's theory with his critique of the «whole conceptual framework» within which Villey's central thesis is set. Villey's conceptual framework is, according to Tierney, based on the claim that a good theory of objective «right» can flourish only in an Aristotelian thought-world, while individualist paradigm of Ockham's thoughtworld can only amount to a bad theory of subjective rights ${ }^{65}$. Tierney develops

63 Tierney, B., «Villey, Ockham...», op. cit., pp. 34-42. See also ID., «Origins of Natural Rights Language: Texts and Contexts, 1150-1250», in The Idea of Natural Rights, pp. 43-77. However, recent studies of Tierney's historical critiques of Villey seem to shed a new, deeper light on the fact that medieval «decretists», commentators of Gratian's 1140 Decretum, were firmly rooted in an objectivistic framework of the classical realistic concept of «ius». The fact that they have at times availed themselves of subjectivist rights-language can be ascribed to their central interest in resolving particular problems, rather than providing conceptual apologetics of «ius». These recent studies, therefore, clearly display how the subjective-rights-discourse of the twelfth century «decretists» could have been semantically correlated with the classic terminology regarding the concept of «ius», without forcing the essentials of this concept in an individualist realm. See SoL, T., «La notion de ius en droit sacramentaire chez Gratien et les décrétistes», Ius Ecclesiae, 27 (2015), pp. 380, 391-394.

64 As Sol points out, Tierney's critique of Villey is essentially dependent on the aptitude of historical and terminological issues for a successful transposition to the specific level of juridical argumentation. In other words, the main question is whether the historical and terminological analysis amount to a conclusion that the notion of subjective rights had already become the principal conceptual tool of juridical language prior to Ockham's nominalist turn. See SoL, T., «La controverse Villey-Tierney...», op. cit., pp. 225, 231-234; ID., «La notion de ius...», op. cit., p. 380 .

65 Tierney labels this approach as a «sort of Manichaean universe». See TiERNEY, B., «Villey, Ockham...», op. cit., p. 30 . 
his objection to such a framework along two lines of argumentation, both pertinent to an adequate understanding of his concept of right.

In the first place, he is convinced that theories of individual rights need not necessarily depend on Ockhamist philosophical premises. He sees no reason why metaphysical realism of Aristotle and Aquinas would be necessarily incongruous with «emphasis on individual rights» ${ }^{66}$.

Tierney's second line of argument is somewhat congenial to the first; he admits to his inability to envision why the three concepts - «ius» as classical objective right, natural law and subjective right - should be inherently inconsistent with one another. To begin with, he claims that, in a juridical discourse, one can simply «emphasize either the objective pattern of relationships» («ius») or the «implied rights or duties of persons to one another - and then again one can focus on either the rights or the duties» ${ }^{67}$. The classical «ius» as just order of human relationships already implies a structure of subjective rights and duties. Tierney continuously claims that there is no essential qualitative difference between postulating the concept of «right» in terms of classical realist «ius» and in the framework of subjective rights. As he himself affirms, «the resulting works may be very different in tone and spirit, but the different emphases do not necessarily imply logical contradictions ${ }^{68}$. He is aware, however, that these are his own conclusions and he clearly acknowledges that in Aquinas's doctrine «right» cannot be said to have a dominant subjectivist implication ${ }^{69}$. In contrast to Aquinas's views, however, Tierney leaves the classical realist «ius» almost completely outside of his juridical argumentation as superfluous ${ }^{70}$. Throughout his analysis, Tierney develops the thesis that a contemporary postulate of the concept of «right» may abstain from a classical realist understanding of «ius» without losing anything significant from juridical argumentation other than mere «emphases», «tone» and «spirit».

«[There exists a] fallacy, widespread among modern jurists and philosophers who are not medieval specialists, that if an idea is not to be found in Aquinas it is not really a medieval idea at all. Another explanation is possi-

\footnotetext{
66 Ibid., p. 31.

67 Ibid., p. 33.

68 Ibid., p. 34.

69 Tierney, B., «Natural Law and Natural Rights: Old Problems and Recent Approaches», The Review of Politics, 64 (2002), p. 393.

70 This has led some authors to conclude that Tierney's concept of right is «fundamentally subjective». See SoL, T., «La controverse Villey-Tierney...», op. cit., p. 223.
} 
ble. It may be that a juristic, distinctively non-Aristotelian theory of natural rights had grown up before Aquinas, that Aquinas did not choose to assimilate such ideas into his Christian-Aristotelian synthesis, but that they did enter the mainstream of Western political thought through other channels. This is the thesis I want to explore ${ }^{71}$.

Once the classical concept of «ius» is discarded as less than essential, Tierney seems to envision the concept of «right» within a structural realm of the exclusive interrelation between subjective (natural) rights and natural law. Although Tierney holds that Aquinas sometimes did use the terms «ius» and «lex naturalis» interchangeably, he affirms that the Angelic Doctor did, in fact, stop short from interrelating the two concepts into a single coherent doctrine $^{72}$. Nonetheless, in his own account of the interrelation between classical realist «ius» and natural law, Tierney highlights that the two concepts coexist harmoniously and could easily be read as complementary in Aquinas, to the extent that both retain the same principle as the underlying sense of rightness or fairness ${ }^{73}$. How does Tierney understand their systematic complementarity?

The concept of «right», in his view, must be founded on a structural interrelation of subjective right-claims with a specific aspect of natural law. The aspect of natural law that is foundational for a theory of rights, according to Tierney, is not the preceptive, but the permissive aspect ${ }^{74}$. Although Aquinas did not assimilate the concept of permissive natural law into his system of «ius» and «lex naturalis» and thereby blocked himself from forming a unique coherent doctrine of right and natural law, the concept was, according to Tierney, operational for the essential understanding of these juridical notions from the

71 TierneY, B., «Origins of Natural...», op. cit., p. 45.

72 See Tierney, B., «Old Problems...», op. cit., pp. 392-394. See also Tierney, B., «Author's Rejoinder», The Review of Politics, 64 (2002), pp. 416-417.

73 The same underlying principle is affirmed, according to Tierney, when we observe that it is «proper for children to respect their parents» (objectively right relationship, «dikaion» or «ius») and if we say «honour thy father and thy mother» (natural law precept). See TiERnEY, B., «Villey, Ockham...», op. cit., p. 26.

74 Tierney, B., «The Idea of Natural Rights - Origins and Persistence», Northwestern fournal of International Human Rights, 2 (2004), p. 8. See also TIERNEY, B., «Villey, Ockham...», op. cit., pp. 33, 44-45; ID., «Origins of Natural...», op. cit., . 68; ID., «Old Problems...», op. cit., pp. 399-406; ID., «Author's Rejoinder...», op. cit., pp. 416-420. Tierney devoted an entire book to a historical presentation of the concept of permissive natural law, see TIERNEY, B., Liberty and Law: The Idea of Permissive Natural Law, 1100-1800, The Catholic University of America Press, Washington D.C., 2014. 
twelfth century onwards ${ }^{75}$. Permissive natural law is that aspect of «lex naturalis» which defines an area of human autonomy and free choice, inherently bounded by the preceptive aspect of natural law (and therefore not envisioned as a state of total, potentially destructive, license and unbounded liberty). Instead of forcing the two concepts - subjective (natural) rights and natural law - in a relation where the former is structurally derived from the latter, Tierney seeks to discover their interwoven ontological content, rooted in human nature. According to his account, rights are manifest in the human capacity for free choice that requires a realm of individual autonomy for its exercise. At the same time, permissive natural law is conceived as person's inherent power of free choice that can licitly be exercised within ontological and moral limits of the natural law in its preceptive mode. In such a scheme, subjective rights may be considered both as zones of autonomous power and as duties based on natural law, without an explicit reference to the classical realist concept of $\langle i u s\rangle^{76}$.

\subsection{Tierney's Concept of «Right» and the Focal Point of Juridicity Inherent in His Argumentation - a Synthesis}

Tierney's insistence on the argumentative cluster of permissive natural law and subjective (natural) rights is paradigmatic to his understanding of the concept of «right».

«Right» is, as seen above, understood as fundamentally subjective right - a power or a claim - intrinsically rooted in the permissive aspect of natural law, which is, in turn, bounded by its preceptive structure. In a definitive account on the concept of «right», therefore, «ius» and «lex» cannot be structurally separated, and the concept of «right» necessarily includes both, natural law and subjective rights.

But what is the focal point of juridicity, i.e., the formal constitutive factor of the juridical dimension regarding facts and relations, in Tierney's theory?

It seems that in Tierney's account juridicity cannot be focalized in the structure of subjective rights alone, since this structure is defined by powers

75 Tierney, B., «Old Problems...», op. cit., p. 399.

$76 \mathrm{Ibid}$., pp. 401, 405. In Tierney's definitive study on the subject of permissive natural law, Aquinas's realist concept of «ius» is never mentioned when doctrine on permissive natural law is assessed with regard to the juridical teachings of the Angelic Doctor. See TiERnEY, B., Liberty and Law..., op. cit., pp. 69-91. 
or claims rooted in the human capacity for free choice that requires a realm of individual autonomy for its exercise. Considered in isolation, the structure of subjective rights does not in itself formally constitute a specifically juridical dimension. Instead, what provides the structure of subjective rights with specifically juridical content, i.e., what situates facts and relations in the realm of juridical obligation, is the natural law. Subjective or «natural» rights are merely a structural extension in the form of an autonomous claim and individual power, but certainly not constitutive carriers of juridical obligation.

Therefore, juridicity is constituted, in the final analysis, by a (natural) legal norm: a law. Natural rights are correlative to (natural) legal norms. To give our definitive critical assessment of this structural move and its philosophical effects for the understanding of the concept of «right», we shall first have to present the theory of another author, John Finnis, who, regardless of his debates with Tierney on important points of historical detail, does not, as we shall seek to demonstrate, structurally differ from Tierney in any significant way as regards the concept of «right» and the focal point of juridicity.

\section{John Finnis, the Centrality of Principles of Practical REASONABLENESS AND SubJECTIVE Rights}

\subsection{A Dispute with Michel Villey on the Terminological Dichotomy between «Ius» and «Lex»}

In his first published academic paper to engage explicitly with Michel Villey's account of the concept of «right» in classical realism, John Finnis, the distinguished Australian professor of legal theory and philosophy of law, entered the debate from a firmly defined argumentative position, which he will continue to sustain in his future works. On that occasion, Finnis criticized Villey's thesis according to which the object of «ius» is the «just share of goods», and has put forward a contrasting argument. He argues that an Anglo-Saxon reader will not find in Aquinas anything resembling a «major opposition» between the terms $\ll$ right» and $\ll$ law $»^{77}$. For classical authors, continued Finnis,

77 FinNIs, J., «Un ouvrage récent sur Bentham», Archives de philosophie du droit, 17 (1972), p. 424. 
law (as the rule of the order of societies) and right (which is, in a certain way, a product of law) were so interwoven in their conceptual relation that these authors occasionally confused one with the other. Villey's claim that the task of the jurist consists in establishing the «just relation» met with Finnis's response that Aquinas has not substantially addressed this task in his Treatise De Iure Et Iustitia, but in the Treatise De Lege of his Summa Theologiae ${ }^{78}$.

In a response published together with Finnis's text, Villey attempted to clarify the dispute by indicating what he took to be Finnis's conceptual confusion between law and right. Law is essentially a rule of conduct, the purpose of which is to «direct human actions», to «make people good» and to conduct them towards both «common good» and their «happiness» or «beatitude». In Thomas Aquinas, right is, instead, never defined as a «law», but as a «just share», a thing, «res iusta». Villey pointed to Finnis's refusal to «conceive of right as something self-standing with regard to law» and wondered whether the problem might indeed be more of a conceptual than merely of terminological nature, given the fact that we cannot postulate a «specifically British interpretation» of the Summa ${ }^{79}$. Since the conceptual autonomy of «right» as a self-standing juridical category with regard to «law» (including natural law as a rule of moral conduct) is evident, Villey, with some academic despair, raised the question of how can it be not clear that «lex and ius manifest themselves as belonging to two different registers» ${ }^{80}$ ? In other words, one may attempt to postulate otherwise, but such an approach is simply not the classical thomistic approach, among other critiques that could be addressed to it.

«Our author, therefore, always faithful to his legalistic departure point, sees right as necessarily derived from law (and that is one way of reducing right to law)» $\gg^{81}$.

Are these qualifications that Villey attributed to Finnis («our author») really sustainable? Surely, Finnis should have been surprised to be called a «legalist», given the fact that the largest portion of his academic work throughout the years has been dedicated to the defence and restatement of the natural law as the basis for human positive law. In what way did Villey's and Finnis's

\footnotetext{
78 Ibid., pp. 424-425.

79 VILLEY, M., «Si la théorie générale du droit», pp. 427-428.

80 Ibid., p. 428.

81 Ibid., p. 429.
} 
discussion transcend the exclusive focus on a historical and terminological dichotomy between «ius» and «lex» and, in fact, touched upon juridical and conceptual issues $^{82}$ ?

\subsection{Finnis's Critique of Villey's Classical Thomistic Understanding of «Ius» - Conceptual Issues}

Finnis's subsequent works reveal that he has continued to develop his concept of «ius» within a fixed framework in which «law» and «right» are necessarily interchangeable and interwoven, to the point where the latter is understood as, essentially, only a necessary logical extension of the meaning of the former. What could be the reasons for his reluctance and refusal to conceptually integrate the classical thomistic understanding of «ius» as elaborated by Villey?

Part of the reason is surely located in Finnis's firm conviction, expressed in his 1980 seminal work Natural Law and Natural Rights, that «the modern grammar of rights provides a way of expressing virtually all the requirements of practical reasonableness» ${ }^{83}$. When referring to the «modern grammar of rights», Finnis understands under this category essentially «subjective rights».

82 Surely a part of the terminological issue on the dichotomy between «ius» and «lex» owes to the fact that in the Anglo-Saxon legal culture the term «law» came to signify the only possible instance of the «right in the objective sense», whereas «right» could have only be used in reference to «subjective rights». This could have, indeed, constituted at least part of the problem for Finnis to enter, on a terminological level, into discussion with Villey's realist concept of «right». The question, however, obviously transcends terminological issues, and moves towards conceptual and philosophical ones, since, to paraphrase Villey, the concept of «right» could not have a «specifically Anglo-Saxon philosophical interpretation». For a synthetical insight of the terminological issue mentioned here, see Pennington, K., «The History of Rights in Western Thought», Emory Law fournal, 47 (1998), p. 237. See also SoL, T., «La controverse Villey-Tierney...», op. cit., pp. 223-224.

83 FINNIS, J., Natural Law..., op. cit., p. 198. Without entering into further detail, it will suffice here to mention that in Finnis's body of work the «principles», as well as the «requirements» of «practical reasonableness» represent his systematic equivalent to traditional conceptual arguments of the more classical «natural law method». Throughout his work, while gradually substituting the traditional natural-law-terminology with his own methodological apparatus, Finnis occasionally reminds the reader that he is accomplishing essentially the same theoretical moves already present in the tradition of natural law, albeit qualified with his own insights. For example, on various occasions, when he asserts something with regard to «practical reasonableness» he is careful to add the explanatory bracket «(.i.e. the tradition of 'natural law')». See ibid., pp. 102-103, 221. 
He famously compliments American jurist Wesley Newcomb Hohfeld for «accommodating satisfactorily» the modern grammar of (subjective) rights into a comprehensive scheme wherein «all assertions or ascriptions of rights can be reduced without remainder» to ascriptions of one or some combination of the following four categories: claim-right, liberty, power, immunity ${ }^{84}$.

«In short, the modern vocabulary and grammar of rights is a many-faceted instrument for reporting and asserting the requirements or other implications of a relationship of justice from the point of view of the person(s) who benefit(s) from that relationship. It provides a way of talking about 'what is just' from a special angle: the viewpoint of the 'other(s)' to whom something (including, inter alia, freedom of choice) is owed or due, and who would be wronged if denied that something $\gg^{85}$.

Finnis is well aware that, when set against the historical backdrop, the concept of subjective rights is on the other, modern side of the «watershed» from the classic concept of «ius». Somewhere in crossing this «watershed» Aquinas's primary meaning of «ius» - «the just thing itself $»-$ has been transformed by «relating it exclusively to the beneficiary of the just relationship $»^{86}$.

There are two crucial points to be made with regard to Finnis's understanding of this crossing of the «watershed» from classical «ius» towards modern subjective rights.

In the first place, it should be highlighted that the main problem Finnis seems to perceive and respond to with regard to this shift of perspective is that, in the subsequent post-Hobbesian modern juridical scheme, the concept of «right» could be seen as altogether detached from «law» ${ }^{87}$. Finnis never re-

$84 \mathrm{Ibid}$., p. 199. Finnis claims that «rights of each of the four Hohfeldian types are spoken of by Aquinas». See FinnIs, J., «A Grand Tour of Legal Theory», in FINNIS, J., Philosophy of Law. Collected Essays: volume IV, Oxford University Press, Oxford, 2011, pp. 115-116. See also HOHFELD, W.N., «Some Fundamental Legal Conceptions as Applied in Judicial Reasoning», Yale Law Fournal, 23 (1913), pp. 28-59; ID., «Fundamental Legal Conceptions as Applied in Judicial Reasoning», Yale Law fournal, 26 (1917), pp. 710-770.

85 FINNIS, J., Natural Law..., op. cit., p. 205. Italics original.

86 Ibid., pp. 206-207. Italics original.

87 «This shift of perspective could be so drastic as to carry right-holders, and their rights, altogether outside the juridical relationship which is fixed by law (moral or posited) and which establishes jus in Aquinas's sense: 'that which is just'. (...) Pushed as far as Hobbes's purposes, this contrast between law and rights deprives the notion of rights of virtually all its normative significance. Hobbes wishes to say that one has most rights when one is in the 'state of nature', i.e. a vacuum of law and obligation (...)», ibid., pp. 207-208. 
ally sees any serious problem in the fact that the whole argumentative cluster of the classical concept of «ius» as «res iusta» is completely absent from the modern and contemporary perspective. Instead, he concentrates the rest of his analysis on the effort, scattered all across his works, to restate the structural value of «law» (natural and positive) for the constitution of the juridical phenomenon and then graft upon it a Hohfeldian scheme of subjective rights. This is a very symptomatic and crucial systematic move to be taken into account in our later analysis on his focal point of juridicity. Finnis seems to be convinced that Aquinas's concept of «ius» and the concept of «right» in general is wholly fixed by law, natural moral or positive law.

«So, if I have a natural - as we would now say, human - right I have it by virtue of natural law \{ius naturale\}; if I have a legal right I have it by virtue of positive law \{ius positivum\}, usually the law specifically of my own state \{ius civile\}. Thus law, natural or positive, is the basis for one's right(s) \{ratio iuris\}.... ${ }^{88}$

The «objective just relationship» that Villey conceived as the structural center of the self-standing classical concept of «ius» is, really, less than essential to juridical discourse in Finnis's scheme, on both sides of the «watershed $»^{89}$. The lack of it does not impoverish juridical discourse in any significant way. The element which is, instead, according to Finnis, truly central and perennial in any classic, modern or contemporary account of «ius» is reflected in the second part of Finnis's definition of the concept - «ensemble of juridical relationships established by rules» ${ }^{90}$.

«These two main meanings of ius - right(s) and law(s) - are rationally connected. To say that someone has a right is to make a claim about what practical reasonableness requires of somebody (or everybody) else. But one's practical reasonableness is guided and shaped by principles and norms, in the first instance by the principles of natural reason, i.e. of natural law - lex naturalis or, synonymously, ius naturale - and then by any relevant and

88 FInNIs, J., Aquinas: Moral, Political and Legal Theory, Oxford University Press, Oxford, 1998, p. 135.

89 Finnis acknowledges that the classical concept of «ius» did, in fact, contain the meaning of the «objective just proportion» within its conceptual structure. He even cites the afore-mentioned ius altius non tollendi passage that represented Villey's frequent argument for his own theory. See FINNIS, J., Natural Law..., op. cit., p. 209.

90 Ibid., p. 208. Italics mine. 
authoritative rules which have given to natural law some specific determinatio for a given community: positive law, i.e. lex positiva or, synonymously, ius positivum, usually ius civile» ${ }^{91}$.

Perhaps with even greater vigour, in Natural Law and Natural Rights and in Aquinas the Australian professor reiterates his initial critiques of Villey's systematic reading of «ius» as an autonomous concept from «lex» in the texts of Aquinas and Roman jurists. Although such view is not completely unintelligible for Finnis (we are before two «distinct notions, but closely related»), it is, in his opinion, grossly «exaggerated» and misleading in its implied distinctions «between law and morality, and between justice and the principles of practical reasonableness $\gg^{92}$.

In the second place, throughout his works Finnis is very explicit with regard to his own position in the crossing of the «watershed» from «ius» towards modern subjective rights. Indeed, he will never again mention «the just thing itself» as Aquinas's primary meaning of «ius», as he did in Natural Law and Natural Rights. Once he structurally secured the concept of law (natural and positive) as underscoring and, indeed, central to the concept of «right», Finnis finds essentially no problem in reading Aquinas's treatment of «ius» through the lens of predominantly subjectivist hermeneutics. Thus, in Aquinas's arguments on justice as allocation to each his right (suum cuique tribuere), Finnis paradigmatically identifies an inherently subjectivist structure of the concept of «ius».

$\ll(\ldots)[\mathrm{I}] \mathrm{t}$ is a sheer mistake to claim, as some have, that [Aquinas] lacked or repudiated the concept of rights in the modern sense, in which a right is 'subjective' in the sense of belonging to someone (the subject of the right). When he defines justice as the steady willingness to give to others what is theirs, Aquinas immediately goes on to treat that phrase as synonymous with their right (ius suum); hence he treats a right/rights (ius/iura) as subjective ${ }^{93}$.

91 FINNIS, J., Aquinas..., op. cit., pp. 134-135.

92 See ID., Natural Laww..., op. cit., p. 228. «Some twentieth-century commentators have thought that Aquinas had in mind a distinction in meaning between ius used in this sense and lex. But he had no interest whatever in making such a distinction, and there is no masked teaching to be found below the surface of his discussions of ius and lex (or anywhere else in his work)». See FinNIs, J., Aquinas..., op. cit., p. 134.

93 ID., «A Grand Tour...», op. cit., p. 116. 
«(...) One cannot properly think of ius without thinking of the other to whom an act, forbearance, or acceptance is, in justice, owed. (...) Which other? The one who, as Aquinas promptly and constantly says, bas the relevant ius. Thus ius can closely match our word 'right', signifying something someone has. Having begun q. 57 by identifying ius as the object of justice, Aquinas, in q. 58 a. 1c, defines justice as willingness to accord to the other bis or her right \{ius suum\}, or synonymously, what is his or hers \{suum\}. How can it be denied that, as something that belongs to the person who has it, ius is 'subjective'»" ?

«To say that jus is something people, one by one, have is to say that it is 'subjective' in the sense that it belongs to subjects (persons)» ${ }^{95}$.

Situating himself firmly on the modern and contemporary side of the paradigmatic «watershed», Finnis is convinced that «there should be no question in wanting to put the clock back». When underscored by a sub-structure of practical reasonableness, the modern idiom of rights is simply «more supple», «more specific in its standpoint or perspective» and «capable of being used with more differentiation and precision than the pre-modern use of 'the right' (jus)» ${ }^{96}$.

94 FinNIS, J., «Aquinas on Ius and Hart on Rights: A Response to Tierney», The Review of Politics, 64 (2002), p. 408. This particular Finnis's quote originated in a debate with Brian Tierney, who criticized precisely this part of the theoretical account of his Australian colleague, namely, the reading of a modern, subjectivist sense of right in Aquinas's classical concept of «ius». As we mentioned before, Tierney is very clear in his claims that, although references to «ius» as « facultas» or «potestas» were in fact operative in the juridical language of Aquinas's time, «right» cannot be said to have a subjectivist implication in the teachings of the Angelic Doctor. Tierney claims that Aquinas «either ignored the subjective meaning or deliberatley excluded it» and that one cannot find any reason for Aquinas's choice in favour of this exclusion «if it was a meaning that he had intended to convey all along». See TiERnEY, B., «Author's Rejoinder», pp. 416-417.

95 See the «Postscript» in FinNIS, J., Natural Law and Natural Rights, p. 423. In the same explanatory section of the second edition of his Natural Law and Natural Rights, in which he comments the original text chapter by chapter, Finnis affirms that «Aquinas's definition of justice, and his prior identification of $j u s$ as the very object (proximate goal and rationale) of justice, entail that (...) in his view, jus (a right) is something that belongs to the subjects of law or moral relationships, and therefore has the essential characteristic of a subjective right». Ibid., p. 465.

96 Ibid., p. 209. In a number of subsequent occasions Finnis revised his position on the importance of the perception of the shift of meaning in the term «right» and its terminological predecessors. «But while it is clear that this shift is correlated with (...) modern conceptions or attitudes which can be vaguely called 'individualist', it seems unlikely that the differing semantics and logic of droit and droits has any truly fundamental importance». See FINNIS, J., «'Natural Law'», in Reason in Action. Collected Essays: Volume I, Oxford University Press, Ox- 


\subsection{Finnis's Concept of «Right» and the Focal Point of Juridicity}

«Thus law, natural or positive, is the basis for one's right(s) \{ratio iuris\}, precisely because the proposition «X has such-and-such a right» cannot rationally be other than a conclusion from, or a determinatio of, practical reason's principles» ${ }^{97}$.

In Finnis's systematic account of the juridical phenomenon the concept of «right» seems to comprise a twofold structure.

In the first place, a «right» in the subjective sense is structurally constituted through a simple act of rational conclusion, or determinatio from the principles of practical reason. Subjective right is the claim itself - rationally arrived at through logical conclusion or determination - about what practical reasonableness requires of somebody (or everybody). Subjective rights represent, therefore, not only terminological «additions»-implied in the classical period, and explicitly characteristic of the modern age ${ }^{98}$ - but also, on a structural level, essentially juridical extensions of natural (or positive) law which, in contrast, stands as a durable foundation of juridicity. This is, however, a subsidiary feature of the semantics of «ius».

The main feature in the structure of the concept of «right» is Finnis's understanding of the «right» in the objective sense: the normative basis for subjective right-claims. The concept of «law», natural or positive, comprehensively constitutes this feature. Law has, according to Finnis, a kind of priority to rights, because «what justice requires is settled by law - moral (natural) or positive $»^{99}$. In his most recent reflection on the topic he firmly highlights that «the object of the the virtue of justice (...) is rights - in the central sense of that English term, the sense in which its correlative is duties, that is, duties of justice resulting from the directives of natural and, where pertinent, just positive law» ${ }^{100}$.

ford, 2011, p. 207. «Natural Law and Natural Rights treats the differences between Thomistic and modern idiom in right(s)-discourse as more significant and interesting than I now think they are». See FinNIS, J., «Aquinas on Ius and Hart on Rights», p. 410. «The 'watershed'

(...) must be regarded as much more a matter of appearance and idiom than of conceptual, let

alone political or philosophical, substance». See FINNIS, J., Natural Law...», op. cit., p. 465.

97 FinnIs, J., Aquinas..., op. cit., p. 135.

98 ID., Natural Law..., op. cit., p. 221.

99 ID., Aquinas..., op. cit., p. 135.

100 ID., «Grounding Human...», op. cit., p. 214. Italics original. 
Thus, much like in Tierney's analysis, although with certain systematic differences ${ }^{101}$, Finnis's theory focalizes juridicity - the constitutive factor of the juridical dimension of facts and relations between persons - in the law, natural or positive just law.

\subsection{A Critical Assessment of Finnis's Concept of «Right» and the Focal Point of Juridicity}

There are several arguments that could be adressed to Finnis's theoretical account from the perspective of Villey's (and, as we shall see later, also Hervada's) theory.

The first critique regards his presentation of Thomas Aquinas's teachings on the matters pertinent to the very concept of «right». Although Finnis highlights that many of his views owe to his understanding of Aquinas's own writings on these topics ${ }^{102}$, we saw that Villey and Tierney strongly oppose such claims by affirming that some Finnis's thesis are simply not compatible with Aquinas's ${ }^{103}$.

A second critique may be established along the lines of Villey's argumentation, and addressed to both Tierney's and Finnis's respective theories of «right». Although Tierney and Finnis differ in particular instances of their respective theories, they nonetheless seem to arrive at similar conclusions as regards the focal point of juridicity. Namely, both authors assume that it is the law (natural or positive just law) that, in the ultimate analysis, constitutes the specifically juridical dimension, and, thus, essentially situates facts and relations in the realm of juridical obligation (or obligation of justice) between persons.

101 Besides the objection to Finnis's subjectivist reading of Aquinas's «ius», Tierney criticizes the Australian jurist's claims that natural rights can be readily, almost automatically derived from natural law, by way of rational conclusions and determinations. For Tierney, as we have already seen, natural rights could, indeed, be compatible with natural law's permissive structure, but without establishing an immediate derivation of the former from the latter. See TiERnEY, B., «Old Problems and Recent Approaches», p. 394.

102 FinNIs, J., Aquinas..., op. cit., pp. viii-ix.

103 In one textual locus Finnis even labels a modality of presentation of the classical concept of «ius» as the «Tierney-Villey characterization», given the convergences of these two, otherwise mutually critical, authors in their consideration of his arguments as clearly divergent from Aquinas's texts. See FINNIS, J., «Aquinas on Ius...», op. cit., p. 408. 
Villey would have addressed at least two sets of arguments in favour of his thesis that such an approach amounts to a position which could fall under the rubric of «legalism».

On one hand, neither Tierney nor Finnis perceive any systematic necessity to postulate (or, from Villey's perspective, to restate) an intermediary dimension of classical «ius» between the law (natural or positive just law) and subjective right-claim on which a «tbing» - «res» - would be constituted as due within an objectively just relation between persons. For Finnis, Villey's «droit naturel» amounts to a superfluous conceptual cluster of content already sufficiently secured at the structural level of «law» (i.e. of the principles of practical reason $)^{104}$ and practically «superseded in living usage ${ }^{105}$. In a culture which understands rights in an overtly individualistic or relativistic fashion, he is convinced that the main imperative is to conceptually reconnect the language of rights to the principles of practical reasonableness ${ }^{106}$.

On the other hand, Finnis's imputations that Villey had misconstrued distinctions between the juridical and moral dimension (or, as he himself says, «between law and morality») would certainly leave a lot to be desired if we would view them from the perspective of Villey's theory. Although, as we have seen, Finnis discards Villey's conception of the juridical dimension as superfluous, he is nevertheless convinced to be faithful to Aquinas's own understanding of such a dimension. At first sight, he seems to adopt his own differentation of the two, moral and juridical dimensions.

«Isn't Aquinas primarily interested in the moral uprightness, the just character, of the duty-bearer, not in the right(s) of the one to whom the duty is owed? Not at all. (...) For he makes it clear that justice's primary demand is that the relevant «external acts» be done (...) So: the good of justice \{bonum iustitiae\} is not the 'clean hands' (better: clean heart) of those who are to do justice but rather - what Aquinas puts at the head of his treatise on justice

\footnotetext{
104 «Undeniably, what is just as between persons in relation to some matter is law's direct concern. But such relationships are not so fundamental that they cannot be explicated and shown to be just(ified) by reference to the principles of practical reason...» See FINNIS, J., «Practical Reason's Foundations», in FINNIS, J., Reason in Action..., op. cit., p. 21. Italics original.

105 «The distinction is simply that the loi naturelle is as such the set of reasons (principles) which justify the assertion of the droit naturel in question. The latter is the former in its application to a specified class of persons and subject-matter. There is distinction but no question of opposition, still less 'opposition capitale'». FINNIS, J., «'Natural Law'...», op. cit., p. 207. Italics of non-French words mine.

106 Ibidem.
} 
- justice's very object: the right(s) of the human person entitled to the equal treatment we call justice» ${ }^{107}$.

«In Aquinas's understanding of justice, rights are as fundamental as duties, and duties as fundamental as rights. We have duties which are not duties of justice, so duty is the wider concept. But when a duty is to another human person, it is a duty of justice, and that other person's right is its very object or point ${ }^{108}$.

These arguments clearly imply that Finnis understands the categories of «otherness» («alteritas») and «outwardness» as somehow foundational for the distinction of the juridical phenomenon from a purely moral perspective ${ }^{109}$. The lack of a more systematic account of the constitutive factors of juridicity as well as of any implication of Villey's concept of «ius», however, seems to lock Finnis's work in a framework in which morality of law is directly translated into juridical categories of what is subjectively due by virtue of such law. And when he does, in fact, attempt to postulate a specifically juridical dimension of the legal phenomenon, Finnis's investigations are confined strictly to the identification of such a dimension in the concept of $l a w^{110}$. Hence, his understanding of the juridical dimension largely differs from Villey's tripartition of this dimension in prior objective order (identified as the principle of practical rea-

107 FinnIs, J., Aquinas..., op. cit., pp. 136-137.

108 Ibid., p. 170. He reiterates the argument in FINNIS, J., «Aquinas on Ius...», op. cit., p. 409.

109 Perhaps this testifies to his perception that a specifically juridical dimension should be built around certain elements constitutive of juridicity, such as those which Villey refers to when he affirms that «right consists in a proportio between res exteriores distributed among a plurality of persons». See VILLEY, M., «Si la théorie générale...», op. cit., p. 428.

110 Finnis reports how legal positivism in its most «pure» form amounts to a position where any necessary connection between law and morality is virtually inexistent. A natural law theory that can enter into a constructive dialogue with more moderate, contemporary currents of legal positivism, assumes a systematic position according to which positive laws are, indeed, social facts which count as genuine reasons to action insofar as «morality makes their social sources and their social-fact content count», with the imperative of avoiding any reduction of «legal theory without remainder to ethics». See FINNIS, J., «A Grand Tour...», op. cit., p. 105, 111. In another assessment of legal positivism, he affirms that «the fact of positivity, without the support of some prior normative principle, can yield neither a rational claim on the deliberations of judge or citizen nor a ground for construing the law as a system». But what normative principle does Finnis refer to? Although human law is not a mere conclusion from moral premises, «its positing and the recognition of its positivity (...) cannot be understood without reference to the moral principles». See FInNIS, J., «The Truth in Legal Positivism», in ID., Philosophy of Law, p. 186. The focus of Finnis's position seems always to be on morality and law, without any reference to a juridical dimension not readily identifiable with law, or ascribable to his concept of rights as its mere extensions. 
sonableness in Finnis's theory, with an unclear differentiation between moral and juridical dimensions), the objective just relation (which Finnis discards as superfluous and instead postulates a rather weak account of subjective rights as extensions from law) and the act of justice itself («to give»).

Finnis's interchangeable use of «ius» and «lex», wherein «lex» is primarily referred to the natural (moral) law as the basis for positive human law, makes it difficult to establish a specifically juridical dimension of natural law, as opposed to a strictly moral one. This distinction was, indeed, foundational for Villey. Nowhere does Finnis satisfactorily and systematically explain how exactly do the conclusions and determinations from the norms of practical reasonableness constitute a specifically juridical «due» as distinct in object from the moral «ought». For example, it is difficult to establish a clear distinction between respective moral and juridical dimensions in the following rightclaim: the right not to be positively lied to in any situation in which factual communication is reasonably expected ${ }^{111}$. Even when enumerating rights that could be taken as always implying also a specifically juridical dimension, such as the «right not to be deprived or required to be deprived of one's procreative capacity ${ }^{112}$, Finnis does not provide us with any further juridical justification, other than a normative cluster of the principles of practical reasonableness. According to Villey's conceptual categories, this cluster would provide us with a good account of the existence of a prior fixed order and of the possibility of its extension in a claim to bring about the act of justice. But the intermediary dimension that Villey understands as constitutive to the nucleus of juridicity is absent from Finnis's theory.

The third and final critique which could be adressed to Finnis's concept of «right» revolves around the fact that his vision of subjective rights bespeaks an almost automatic and somewhat uncritical inheritance of a predominantly individualistic philosophical context in which subjective rights originated. Only the modern side of the «watershed», where the juridical phenomenon was understood to be concentrated in the sphere of the individual and his powers, could yield a framework of thinking about law as not only a source of moral obligation, but also as an immediate foundation of juridical obligation conceived in an exclusively subjectivistic fashion ${ }^{113}$.

\footnotetext{
${ }^{111}$ FinNIS, J., Natural Law..., op. cit., p. 225.

112 Ibidem.

113 See Demelemestre, G., «La réception de l'interprétation française des theories du droit naturel dans le monde anglo-saxon», Archives de philosophie du droit, 58 (2015), pp. 405-406.
} 


\section{Javier Hervada, Right as «RES IUsta» (A Just Thing) AND Classical Juridical REALISM}

In the simplest line of argumentation, readily translatable into phenomenological categories close to experience and with sharp philosophical vigour that permits a clearer understanding of the specificity of the juridical dimension, the Spanish civil and canonical jurist, Javier Hervada, elaborated a restatement of the central reference point of classical juridical realism: right is primarily a thing, «res iusta» ${ }^{114}$. His account of the concept of «right» is rooted in the understanding that Aquinas, in his Treatise on Justice (S.Th. II-II, q. 57-58) in Summa Theologiae ${ }^{115}$, presented the juridical phenomenon principally as a thing, «res», a corporeal or incorporeal thing, which is due to the subject because it has been attributed to him ${ }^{116}$.

\subsection{The Centrality and the Systematic Context of «Right» in Classical furidical Realism}

Within the philosophical context of classical juridical realism - in the strict sense of the term ${ }^{117}$ - Hervada adopts a twofold starting point en route to his presentation of «right». On one hand, he firmly contextualizes his analysis of the juridical phenomenon within the conceptual realm of justice - «ius suum cuique tribuendi» - where right is the object of justice ${ }^{118}$, as we already

${ }^{114}$ Hervada, J., Critical Introduction..., op. cit., pp. 25-31; ID., What is Law? The Modern Response of Furidical Realism: An Introduction to Law, Wilson \& Lafleur Ltée, Montréal, 2009, pp. 43-44, 48-49; ID., Lecciones propedéuticas de filosofía del derecho, EUNSA, Pamplona, 1992, pp. 198-199, 230-232; ID., «Apuntes para una exposición del realismo jurídico clásico», Persona y Derecho, 18 (1988), pp. 284-285.

115 See SCHOupPE, J.-P., «El realismo jurídico de Javier Hervada», in Natura, Ius, Ratio: Estudios sobre la filosofía jurídica de favier Hervada, Rivas, P. (ed.), Ara Editores, Lima, 2005, p. 36. For a more extensive account of Hervada's philosophical itinerary, and his intellectual «conversion» to classical juridical realism, see DeL Pozzo, M., L'evoluzione della nozione di diritto nel pensiero canonistico di Favier Hervada, EDUSC, Roma, 2005, pp. 47-73, 125-172, 329-354.

116 Hervada, J., «Le droit dans le réalisme juridique classique», Droits, 10 (1989), p. 31.

117 Classical juridical realism is a current in philosophy of law whose authors «not only apprehend the reality (moderate philosophical realism) in order to discover in it the most fundamental nucleus of juridicity inherent in the very being of persons (juridical realism in a broad sense of the term), but also consider that juridical science is the art of 'that which is just' and that the proper sense of 'right' is that of a good which is due in justice..». See ScHouppe, J.-P., «El realismo jurídico...», op. cit., pp. 41-42.

${ }^{118}$ Schouppe, J.-P., Critical Introduction..., op. cit., p. 27. 
saw in the exposition of Villey's account of «ius». However, this conceptual context is only a backdrop to Hervada's experiential, almost phenomenological, starting point of grasping the juridical phenomenon.

«That point of departure is none other than an easily verifiable social fact: things are attributed to different subjects, in other words, things are distributed (...) Justice does not attribute things, but follows the fact that they are already attributed $\gg^{119}$.

The act that is foundational of «right», i.e., which renders a thing somebody's suum and establishes a relation of «suitas» between a thing and its title-holder, is the act of attribution or distribution of things ${ }^{120}$. This act is determined by the category of «title», or «that which causes the attribution of a thing to a specific subject ${ }^{121}$, for example, legislation, custom, contract, juridical fact or human nature. Despite the fact that it is, indeed, foundational, the relation of $\ll$ suitas $»$ does not yet formally constitute $\ll$ right ${ }^{122}$. The constitutive factor of juridicity, which Hervada understands as formally constituting a thing as «right», is dependent on the property of a thing to be or to be able to be in the sphere of power of another person or susceptible to bis interference ${ }^{123}$. The relation of «suitas», therefore, conjugated with this property of the thing (susceptible to be in the sphere of power or interference of another) creates a relation of debt with regard to one who interferes or could interfere (the debtor), as well as his correspondent obligation to re-establish or respect the situation of non-interference ${ }^{124}$. This structure of the juridical phenomenon contains all the elements characteristic of juridicity ${ }^{125}$ : the foundational relation of «suitas» as the effect of attribution by a title, the outwardness of things ${ }^{126}$, the otherness

\footnotetext{
119 Ibid., pp. 9-10.

120 HervaDA, J., «Exposición del realismo...», op. cit., p. 289.

121 ID., Critical Introduction..., op. cit., p. 34.

122 ID., Lecciones propedéuticas..., op. cit., pp. 202, 231.

123 ID., «Exposición del realismo...», op. cit., p. 285; ID., Lecciones propedéuticas..., op. cit., p. 231.

124 ID., Lecciones propedéuticas, pp. 202-203.

125 This list of the essentialities of juridicity is a synthesis of Hervada's own position on this topic. See Hervada, J., «Exposición del realismo...», op. cit., p. 292. For a congenial exhaustive enumeration of the characteristic elements of juridicity, see DEL PozZO, M., L'evoluzione della nozione..., op. cit., p. 346.

126 All of the things susceptible to be constituted as rights «must have a common characteristic: they are things that have an external dimension (res exteriores), which, in themselves or in their manifestations, spring from the intimate sphere of the subject». See HERVADA, J., What is Law?
} 
characteristic of justice as a virtue of social - intersubjective - relation (which includes at least two subjects in a distinct complementary position wherein at least one of them is a debtor ${ }^{127}$, and, finally, the obligation arising from the relation of debt, as described above.

But where is the essence of the concept of «right» in this structure of juridical phenomenon? Now, «right» in the primary sense - the «suum», that which may be declared with regard to the title-holder as «his own», his «due» in the virtue of an exclusive attribution of a thing - is not a law, nor a subjective right. According to Hervada, «right» is each person's own thing, the just thing, «res iusta». What constitutes the «suum» of the person owed in justice is the thing itself ${ }^{128}$. In full accordance with the postulates of juridical realism in the strict sense, «right» cannot be understood as something that belongs to a purely formal, idealistic level, but has to be understood and fulfilled on the level of reality in all its radical givenness ${ }^{129}$. Of course, «right» is not, ontologically speaking, the thing in itself, in its substance, but only insofar as attributed to a title-holder with whom another person is in a relation of debt ${ }^{130}$. Things - all the things that are susceptible to be constituted as «right» - certainly maintain their substantial status ${ }^{131}$. Nevertheless, the perception of «right» as a concrete thing is indispensable for its correct conceptual apprehension ${ }^{132}$ and the «reification» of «right» does not imply a substantialization of a concept, but only a discovery of the foundation «in re» of that concept $\mathrm{t}^{133}$.

pp. 48-49. «The intimate sphere of man or his incommunicable - what remains outside of social relations - does not constitute 'right'». See HERVADA, J., Lecciones propedéuticas..., op. cit., p. 225. «Outwardness - this must be clear - does not necessarily mean that it is a thing that can be grasped, in itself, by the senses. It is sufficient that, in that it has some exterior manifestation, it be the object of human relations and, therefore, capable of being grasped or interfered with directly or indirectly (...) - through others. For example, when we speak of a right to religious freedom, it is clear that we are not speaking of the act of faith, as if it could in itself be usurped by others. But, mediately it could be interfered with (...) in its manifestations, and a person may be the object of coercion». See Hervada, J., Critical Introduction..., op. cit., p. 26.

$127 \ll$ The relation of justice requires that each subject is radically 'other'. If otherness is not perfect, a relation of justice in the proper sense cannot be established, since, to the degree that the subjects are not radically 'others', there can be no full and perfect distinction between the 'suum' of each of them». See HervaDA, J., «Exposición del realismo...», op. cit., p. 292.

${ }^{128}$ Hervada, J., Critical Introduction...», op. cit., pp. 25-26.

129 See ID., What is Law?..., op. cit., p. 47.

${ }^{130}$ ID., Lecciones propedéuticas..., op. cit., p. 198.

131 Ibid., p. 230.

132 Schouppe, J.-P., Le réalisme juridique, E. Story-Scientia, Bruxelles, 1987, p. 154.

133 Del Pozzo, M., L'evoluzione della nozione..., op. cit., p. 349. 
Perhaps such a framework of the concept of «right» may seem rather difficult to conceive of, or even be scandalous to a person professionally or culturally formed exclusively in a positivistic or individualistic concept of «right».

$\ll(\ldots)[\mathrm{H}] \mathrm{e}$ will probably feel called to correct me: the house is not a property right, but its object; said otherwise, he would have to say that I have the property over the house. (...) In other words, at each step I have been confusing a right with its object. There is no such confusion, though» ${ }^{134}$.

Under the rubric of «thing» Hervada truly does understand «right» precisely as the concrete individual thing - corporeal or incorporeal - attributed to somebody on the basis of a title, situated within the specific juridical reality in virtue of relation of debt. The thing is here understood in the broadest possible sense, as a universal convertible with being ${ }^{135}$ for the purpose of reference to a concrete reality, and surely not for imparting an ontological status. «Res iusta», therefore, can be a car, a payment, a house, an hour of playing tennis on the tennis-court no. 2 in that particular recreational complex, a portion of food, a selected meal, free movement across a border, the use of a public road, a presence before a tribunal with a claim, good reputation, or enjoying an experience of hearing a concert on seat no. 24 in the fifth row of that particular concert venue at that particular time. And, yes, a person (with the necessary presupposition that a possible implication ${ }^{136}$ of anything resembling a «reification» of a person is completely excluded).

${ }^{134}$ Hervada, J., What is Law?..., op. cit., pp. 43-44.

135 Schouppe, J.-P., Le réalisme juridique..., op. cit., p. 154.

${ }^{136}$ Hervada, J., Critical Introduction..., op. cit., p. 25. As said before, the designation «thing» is not meant as a tool for conferring an ontological reality to something or somebody. It is, rather, understood in the broadest possible sense of reference to an already established concrete reality in all the givenness of its ontological intensity, as opposed to an idealistic separation of the concept of «right» from reality. With regard to a person as «res iusta»- a thing due in justice, a «suum»-it must be highlighted that classical juridical realism seeks to express a juridical reality of how a concrete be or she may constitute a «res iusta», «something» owed in justice to another person, in a variety of juridical relations. For example, in marriage, the object of marital consent - indeed, a covenant not only a contract - are «the very persons of the spouses that mutually give and accept each other in their conjugality, that is, in that dimension of human existence inscribed in the primary sense of sexual differentiation». See ERrázURIZ, C. J., «El matrimonio como conjunction entre amor y derecho en una optica realista y personalista», Scripta Theologica, 26 (1994), p. 1034. The spouses form an intentional motion towards marriage, but not with an act of will directed primarily towards the institution of marriage or towards the communion of life and love itself, but primarily towards «the person of the other spouse in his or her conjugality». See HervadA, J., «Esencia del matrimonio y consentimiento matrimonial», in ID., Vetera 
An important argument for the comprehension of Hervada's juridical realism against a false premise of substantialization of juridical phenomena ${ }^{137}$ is the postulate of the focal point of juridicity as essentially a relation between a thing - «right» - and at least two persons, one who is the title-holder and to whom the thing is due in a relation of justice, and the other who is the debtor ${ }^{138}$. As we mentioned before, it is precisely this relation that renders the thing a «right».

\subsection{The Systematic Locus of Subjective Rights and Law in Hervada's Furidical Realism}

Since in Hervada's theoretical elaboration of classical juridical realism the primary meaning of «right» is reducible neither to subjective rights nor to law, it will be interesting to see what structural place the Spanish jurist assigns to these juridical concepts in his system.

Subjective rights as faculties or powers that the individual may claim over things, according to Hervada, certainly exist, but only as a consequence - a manifestation, a derived juridical meaning - of the primary meaning of «ius» as a just $t$ thing ${ }^{139}$. They do not, in any terms, substitute the thing due in justice and, therefore, do not constitute a new kind of essence to the concept of «right ${ }^{140}$. It is, however, crucial to understand that the concept of subjective rights made its entrance to juridical doctrine precisely with the intention to substitute the realistic concept of right. This occurred in a philosophical context which Hervada, together with Villey, ascribes to the doctrine of William

et Nova: Cuestiones de derecho canonico y afines: 1958-2004, Navarra Gráfica Ediciones, Pamplona, 2005 , p. 937 . The act of marital consent actualizes natural potentialities for conjugality inherent in the person's respective masculinity or femininity, within a relational perspective towards the other person of the opposite sex. This same act converts the personal dominion of a spouse over his own personal structures of the capacity for conjugality in a «res» of the other spouse, in order to constitute, among other effects, a specifically juridical dimension of being due to each other in a spousal dimension. See Puig, F., La esencia del matrimonio a la luz del realismo jurídico, Navarra Gráfica Ediciones, Pamplona, 2004, pp. 235-248.

137 «The thing in itself is not 'right', but things are susceptible to constitute 'right'». See DEL Pozzo, M., L'evoluzione della nozione..., op. cit., p. 56.

138 Hervada, J., Lecciones propedéuticas, p. 231.

139 ID., «Exposición del realismo jurídico clásico», pp. 288-289. See also ID., Lecciones propedéuticas..., op. cit., p. 243.

${ }^{140}$ ID., What is Law? ?.., op. cit., pp. 45-46. 
Ockham $^{141}$. Ockham and his intellectual successors relegated the thing itself, «res», to a structural position where it is considered an object of «right», a reality over which the individual extends a moral faculty or power ${ }^{142}$. The radical error of Ockhamian theory of subjective rights consists in its adherents' inability to perceive that «right» and the thing - «res» - are not, in fact, separable. Such conceptual schism of reality would lead, and has, indeed, led to a constitution of «right» detached from the «res iusta». «Right» could, then, be conceived as perfectly claimable in its essential property of faculty or power, regardless of the concrete thing (which would become a secondary juridical phenomenon) and its being due: it would be due only insofar as it is claimed ${ }^{143}$. Justice would, in such a theoretical scheme, essentially consist in giving to each his own faculty or power to claim, and not in giving the thing itself ${ }^{144}$. How can subjective rights exist autonomously without any reference to the pre-existence of the «res iusta» and what would, in such a scheme, represent a foundation of such claimability?

Earlier, we saw how Villey did seem to imply that one could, in fact, postulate a juridical dimension of natural law ${ }^{145}$, but then stopped short from proposing a systematic distinction and elaboration of such dimension of law. In Hervada's system, law is an element of the juridical phenomenon precisely because of its relation with «right», that is, with the just thing ${ }^{146}$. What does this relation consist in? The law, natural or positive, is the title which attributes certain things to the title-holders, and thus founds «right», insofar as those things are susceptible to be included in relations of debt ${ }^{147}$. The norm of law is necessarily juridical in itself only insofar as it is, in its own specific way, structurally linked to all the elements of juridicity: foundational relation of «suitas», outwardness, otherness and, finally, the relation of debt. Hervada affirms that, within the broader term of natural law - which also includes

\footnotetext{
${ }^{141}$ Hervada, J., Lecciones propedéuticas..., op. cit., p. 239.

142 Ibid., p. 241.

143 Ibid., pp. 242-243. See also Schouppe, J.-P., Le réalisme juridique..., op. cit., p. 167.

144 Hervada, J., «Exposición del realismo...», op. cit., p. 289.

145 The idea is made almost explicit especially in VILLEY, M., «Si la théorie générale...», op. cit., p. 429. See also his various collateral arguments in VILLEY, M., La formation de la pensée..., op. cit., pp. 592-606.

${ }^{146}$ Hervada, J., Critical Introduction..., op. cit., pp. 122-124, 154-155. See also ID., «Exposición del realismo jurídico clásico», pp. 294-295; ID., Lecciones propedéuticas..., op. cit., pp. 531-535; ID., What is Law?..., op. cit., pp. 142-145.

147 ID., «Exposición del realismo...», op. cit., p. 294.
} 
a moral dimension of natural precepts, indeed, «the more relevant aspect of such normativity» ${ }^{148}$ - some natural norms, however, have a specifically juridical dimension: those that state a duty of justice ${ }^{149}$. These norms compose the juridical natural law ${ }^{150}$. The importance of Hervada's (perhaps unique) theoretical attempt to postulate a specifically juridical dimension of natural law might seem quantitatively underdeveloped, given the fact that Hervada dedicates very few arguments (and in a rather unsystematic way) to the elaboration of this matter. We believe that he himself has undergone a progressive growth in his understanding of the systematic position of the juridical dimension of natural law, and that, in certain ways, which transcend the concrete scope of this particular paper, he has not taken this aspect of his theory to its full argumentative consequences.

\section{Final Critical Remarks on the Course and Results OF THE Debate Regarding THE CONCEPT OF «RighT» AND THE FOCAL POINT OF JURIDICITY}

All the presented authors could be said to subscribe to an «objectivist» account of juridical phenomenon, that is, to a classical juridical realism in the broad sense of the term ${ }^{151}$. In short, they all endorse a juridical doctrine which affirms the existence of objective norms as expressions of the demands of justice, norms which, in turn, constitute criteria of legitimacy of positive law and structurally precede it. All the authors are in explicit or implicit argumentative dialogue between them. The theory of each of them may represent an argumentative critique to the approach and system of the other.

First of all, among the four authors presented, Villey and Hervada could be categorized also as adherents of classical juridical realism in the strict sense. In contrast to Tierney and Finnis, they clearly affirm that there is a real structural distinction between «right» and law (reflected in separate treatises on each of these concepts in Aquinas's Summa Theologiae), and that the former is

\footnotetext{
148 Hervada, J., Lecciones propedéuticas..., op. cit., p. 531.

149 ID., Critical Introduction..., op. cit., p. 124.

150 ID., Lecciones propedéuticas..., op. cit., p. 532. See also ID., What is Law?..., op. cit., pp. 143-144.

${ }^{151}$ For definitions and differences between an «objectivist» juridical doctrine and classical juridical realism in the strict sense, see supra note 116. See also SchoupPE, J.-P., Le réalisme juridique..., op. cit., pp. 110, 174-176; and ID., «El realismo jurídico...», op. cit., pp. 41-42.
} 
not reducible to the latter. Subjective rights are, to both Villey and Hervada, derivations and particular analogical manifestations of the central significance of the concept of «right». The main characteristic of classical juridical realism in the strict sense is the identification of «right» with the thing due in justice on the basis of a relation of debt ${ }^{152}$. We have seen that Hervada, and, to a certain, perhaps less elaborated ${ }^{153}$, extent Villey, adhere to this position.

We have already presented Tierney's and Finnis's mutual critiques. Regardless of their differences, these two authors also firmly remain on the side of what can be characterized as the «objectivist» account of juridical phenomenon (i.e., classical juridical realism in the broad sense of the term). They, however, do not postulate anything similar to Villey's and Hervada's real structural distinction between «right» and law. They disagree with Villey's and Hervada's view that «right» should not be reducible to law to the point where law is considered the essential carrier (or the focal point) of juridicity.

Each of the authors' two argumentative blocks, Tierney and Finnis, on one side, and Villey and Hervada on the other, point to some necessary structural improvements of potentially deficient points in accounts of the concept of «right» of their interlocutors in the debate. After all, this seems to be the desired scope of each scholarly debate: an attempt to illuminate a contrasting view and expose one's own to a potential critique in the hope that all participants of the debate will acquire a deeper insight of the subject-matter along the way, even if they do not alter their initial views.

152 Schouppe, J.-P., Le réalisme juridique..., op. cit., p. 176; ID., «El realismo jurídico...», op. cit., p. 42. See also Del Pozzo, M., L'evoluzione della nozione...», op. cit., p. 135.

153 According to an ongoing academic debate in this particular matter, Villey's adherence to realism in the strict sense of the term could be limited and compromised by his frequent references to «right» as predominantly a relation - «objective just relation»- that is, as an ordered proportion between external things distributed between persons, rather than a thing. According to this view, Villey seems to employ the reference to the thing in definitions of the concept of «right» only in a derivative, posterior sense; namely, when «right» as essentially a relation is seen from the perspective of the individual as his «just share». For this side of the debate, see SCHOUPPE, J.-P., Le réalisme juridique..., op. cit., pp. 136-137; and ID., «Réflexions sur la conception...», op. cit., pp. 153-154. On the other hand, it has also been affirmed that Hervada, indeed, seems to go further than Villey in elaborating details of philosophical and especially juridical distinctions between juridicity and «right». In Hervada, juridicity is, essentially a relation, while «right» is always defined in its primary reference to the thing as its substance (with a clear distinction between, as we have already seen, the substance of the thing and the substance of «right»). If we keep in perspective Hervada's more juridical approach as well as Villey's difficult and polemical context of having to affirm «right» as both, a «just relation» contra subjectivism in general, and as a «just thing» contra the concept of «right» as essentially subjective rights, than the views of two authors can be viewed as, indeed, convergent. See Sol, T., «La notion de droit...», op. cit., pp. 338-342. 
Hervada (as well as Villey) insists that the contemporary «objectivist» account of the juridical phenomenon should structurally distance itself from reserving the concept of «right» exclusively to subjective rights, as well as from consideration of law as the focal point of juridicity. The focus of the concept of «right» should, instead, return to the just thing itself. Tierney's and Finnis's respective positions on the concept of «right» lack altogether classical juridical realism's intermediary dimension between the concept of law and rights understood as, essentially, subjective rights. It is difficult to clearly perceive what is specifically juridical, as clearly distinct from exclusively moral, in their accounts of natural law and individual rights. In their systems we encounter only post-Ockhamian essential juridical entities - subjective rights - objectively rooted in moral foundations that have a normative structure. Villey labelled this approach as «legalistic», despite its clearly «objectivist» postulates. It is difficult not to wonder how much Tierney's and Finnis's theoretical positions would benefit from conceiving «right» as essentially the just thing, as well as from the removal of the focal point of juridicity away from the law towards classical realism's relation of debt between persons. The concept of law would not be diminished or in any way compromised by such integration. It could, instead, be systematically interrelated to the just thing itself and oriented more towards Aquinas's genuine realistic concept of «right». Subjective rights could, then, only constitute a derivative - important and inherent, but not primary structural moment of «right» which is necessarily arising from juridicity.

On the other hand, Tierney's, and especially Finnis's theory can be considered as an invitation and, indeed, an imperative to intellectual successors of Villey and Hervada for developing a more systematic account of natural law in classical juridical realism. The fact that Aquinas himself treated concepts of «right» and law systematically and textually in their separate respective doctrinal loci of his Summa Theologiae does not mean that he understood the two things, «lex» and «ius», as elements of two autonomous, absolutely non-convergent, juridical and moral dimensions. Villey rarely hints at the need to postulate a specifically juridical dimension of natural law. Hervada is more explicit on the subject, and in various, though somewhat underdeveloped arguments integrates the element of juridical natural law into his theory. In a theory that represents a contemporary restatement of classical juridical realism it could well be that a systematic fully-fledged integration of juridical natural law in all its structural consequences is precisely what is most lacking. Once the concept of «right» as a «just thing» is secured as the central feature and, indeed, hermeneutical key to the whole system, the next logical systematic step seems 
to resolve itself into a restatement also of Aquinas's doctrine of law, especially natural law, in its juridical dimensions. Perhaps this would render thomistic juridical realism itself more intelligible to those who currently subscribe to it only in a broad sense of the term.

Hervada's analysis of the structure of juridicity is an important contribution to be taken into serious account in establishing a point of contact between the two argumentative blocks. As we saw earlier, Hervada's focalization of juridicity in the relation of debt between persons with regard to the thing constituted as «just thing» points to both a prior attribution of the thing to the title-holder (through a title from which a relation of «suitas» arises) as well as towards a posterior structural moment of subjective right-claim, without being reducible to each of these moments. The adherents of the classical juridical realism in the strict sense could, indeed, improve on providing a systematic account of the moment of attribution of the thing through an elaboration of juridical natural law as the title of attribution. At the same time, Finnis, Tierney and their intellectual successors could benefit from integrating into their account a specifically juridical dimension between the structural moment of attribution through a title (law, natural and positive, among other titles) and the subjective right-claim. Of course, such integration would require something resembling an authentic intellectual «conversion» to classical juridical realism in a strict sense, wherein «right» is each person's own thing, the just thing, «res iusta». Hervada would certainly be the first to admit that he himself once underwent a «conversion» of this kind ${ }^{154}$.

\footnotetext{
${ }^{154}$ For a more detailed account of the intellectual «conversion» of Javier Hervada during the summer of 1980 as, indeed, a discovery of a new hermeneutical «quid» in the form of classical juridical realism within the scheme of his previous position (which he himself labelled as «conceptual» classical realism centred around relational juridical structures of social reality inspired on his previous understanding of Thomism), see DeL Pozzo, M., L'evoluzione della nozione..., op. cit., pp. 47-49, 125-132, 135-138, 329-333. See also the words of Hervada himself published in the Appendix of Del Pozzo's work, at pp. 588-597.
} 
